\title{
Internal Control in PCR for Mycobacterium tuberculosis: Usefulness and Improvement of the Diagnosis
}

\author{
Elizabeth Cortez-Herrera $^{2 *}$, Rosa Dea Sperhacke ${ }^{1}$, Daniela Becker ${ }^{2}$, Afrânio Kritski ${ }^{1}$, \\ Arnaldo Zaha $^{3}$ and Maria Lucia Rosa Rossetti ${ }^{4}$ \\ ${ }^{I}$ Instituto de Doenças do Tórax; Hospital Universitário Clementino Fraga Filho Universidade Federal do Rio de \\ Janeiro; Rio de Janeiro - RJ - Brasil. ${ }^{2}$ Centro de Desenvolvimento Científico e Tecnológico do Rio Grande do Sul; \\ Fundação Estadual de Produção e Pesquisa em Saúde; Porto Alegre - RS - Brasil. ${ }^{3}$ Centro de Biotecnologia; \\ Universidade Federal do Rio Grande do Sul; Porto Alegre - RS - Brasil. ${ }^{4}$ Universidade Luterana do Brasil; Canoas \\ - RS - Brasil
}

\begin{abstract}
The aim of this work was to construct and test a plasmidial Internal Control (IC) to detect the inhibition in the PCR test for $\underline{M}$. tuberculosis and also its contribution for a Public Health Laboratory routine. The IC was a 600-bp of DNA linked to a plasmid with the same primer sites, allowing the amplification with the 245-bp diagnostic fragment. The amplification of the positive samples rendered the IC and the diagnostic fragment; instead negative samples only showed the IC. A total of 149 tuberculosis samples were studied and introduced the IC to monitor. Results showed 3.3\% of the samples without amplification of the IC, suggesting the inhibition. These samples showed results in accordance with the clinical results. The objective of the IC was to identify the false negative results.
\end{abstract}

Key words: Polymerase Chain Reaction, tuberculosis, internal control, nucleic acid amplification, uracyl DNA glycosilase

\section{INTRODUCTION}

The need of the sensitivity, high speed and the hope of shortening the time for the detection and identification of Mycobacterium tuberculosis prompted several investigators to develop the molecular assays for the diagnosis of the tuberculosis (TB) (Eisenach et al., 1990; Noordhoek et al., 1994; Folgueira et al., 1996; Jatana et al., 2000; Portillo-Gómez et al., 2000; Patnaik et al., 2001; Singh and Seth, 2002). Although the commercial kits, based on the PCR (Beavis et al., 1995; Kunakorn et al., 1999) or other nucleic acid amplification (NAA) detection are now available, their use has been limited mainly to the developed countries, because of high costs and lack of the laboratory infrastructure to perform them. Despite its high sensitivity, the PCR presents some problems in the amplification procedure, mainly due to inhibitors that could give mostly false negative results. The presence of such substances seems to be abundant in the clinical specimens, especially in the pleural fluid, cerebrospinal fluid, peripheral blood and sputum, which often require prompt diagnosis in the public health laboratories (Brisson-Nöel et al., 1989; Victor et al., 1992; Kolk et al., 1994; Wilson, 1997).

Several methods have been adopted in order to monitor the presence of such inhibitors in the PCR

${ }^{*}$ Author for correspondence 
procedure (Eisenach et al., 1991; Folgueira et al., 1993; Totsch et al., 1994; Osaki et al., 1997; Li et al., 1998; Brightwell et al., 1999). Here, we report the IC construction and experimental validation for use in the TB diagnosis. The IC contained the same primers recognition sites as the $M$. tuberculosis IS6110 DNA diagnostic fragment. Several DNA TB samples were tested in order to monitor the IC performance to detect the presence of the inhibitors and to identify false negative results.

\section{MATERIALS AND METHODS}

\section{Plasmid, primers and exogenous fragments}

The pAMP1 plasmid (Invitrogen) was used to construct the IC. The primers named INSI and INS2 corresponding to the insertion element IS6110 of M. tuberculosis, synthesized with the adapter fragments and phosporilated (Balavoine, 1996) (INS1: 5'- CUA CUA CUA CUA CGT GAG GGC ATC GAG GTG GC-3', INS2: 5'CAU CAU CAU CAU GCG TAG GCG TCG GTG ACA AA-3') were also used. The enzyme Uracyl DNA Glycosilase (UDG) was added to perform the cloning procedure. The exogenous 600-bp fragment was obtained from PUC13 plasmid digested with EcoRI enzyme, purified and incubated with Klenow polymerase so as to generate the blunt ends (Sambrook et al., 1989). In order to exclude the presence of any INSI and INS2 complementary regions in the 600-bp fragment, the PCR under various annealing conditions were performed.

Internal control construction- The pAMP1 linear plasmid, the 600-bp fragment and UDG enzyme were mixed and incubated at $37^{\circ} \mathrm{C}$ for $30 \mathrm{~min}$, purified in Microspin columns (Qiagen) and used to transform XL-1 blue Escherichia coli competent cells by the thermal shocking at $42^{\circ} \mathrm{C}$ (Sambrook et al., 1989), then plated onto Luria Bertani (LB) solid medium containing Ampicilin $(100 \mu \mathrm{g} / \mathrm{ml})$ and incubated overnight at $37^{\circ} \mathrm{C}$.

To screen and select the recombinants, each bacterial colony was picked up with a toothpick and dissolved in $500 \mu \mathrm{l}$ of TE buffer $(10 \mathrm{mM}$ Tris$\mathrm{HCl}, 1 \mathrm{mM}$ EDTA, pH 8.0). Denatured at $97^{\circ}$ for 5 $\min$ in a thermocycler and centrifuged at 10,000 $\mathrm{rpm}$ for $3 \mathrm{~min}$. Ten microlitres of the supernatant were added to a PCR mix that contained $2.5 \mathrm{U}$ of recombinant easy Taq DNA polymerase (LGC
Biotecnologia, Brazil); 50 pmoles of each INSI and INS2 primer, $10 \%$ reaction buffer $10 \mathrm{X}(100$ $\mathrm{mM}$ Tris- $\mathrm{HCl} \mathrm{pH} 8.3,500 \mathrm{mM} \mathrm{KCl}, 0.2 \%$ gelatin and $30 \mathrm{mM} \mathrm{MgCl}{ }_{2}$ ), $200 \mu \mathrm{M}$ dNTPs. The positive recombinants were re-inoculated in duplicate onto LB medium plates for further purification and PCR amplification to confirm the IC cloning.

\section{Clinical specimens}

One hundred and forty five clinical specimens, collected from January 2002 to February 2003 in the Central Laboratory of Public Health, Rio Grande do Sul, Brazil (Lacen/RS) that included 2 sputum, 4 BAL (bronchoalveolar lavage), 87 CSF (cerebrospinal fluid), 14 blood specimens, 21 biopsies, 8 pleural fluid specimens, 5 urine, 4 ascitic specimens, 3 pericardic fluid, and 1 abscess specimen were processed. From the total studied specimens, 111 corresponded to negative and 38 to positive ones. The final diagnostics were obtained from the information recorded in the National System of Notification Diseases (Sinan) and from the medical charts reviewed by the trained personnel as described by Sperhacke et al. (2004). All the clinical samples were decontaminated with $4 \% \mathrm{NaOH}$ and cultured in Ogawa medium (Kudoh and Kudoh, 1974). DNA from all the specimens was extracted and purified according to Rossetti et al. (1997). In order to verify the differences between the results, all the clinical specimens were tested with and without IC. For the PCR, ten microlitres of the DNA from the specimens were mixed to 5 fg of IC DNA and the PCR mix reagents. The results obtained by the PCR were compared to the clinical diagnosis and bacteriological results.

\section{Amplification assays}

The PCR amplifications with the clinical specimens described above were based on the IS6110 (Eisenach et al., 1990), according to the protocol used by Rossetti et al. (1997) included the addition of the IC. Each set of the PCR performed in the laboratory was controlled by the use of a positive control (PC), previously obtained by the cloning as in the IC. The $50 \mu \mathrm{l}$ PCR amplification mixes contained $10 \mathrm{mM}$ Tris- $\mathrm{HCl}(\mathrm{pH} 8.3), 50$ $\mathrm{mM} \mathrm{KCl}, 3 \mathrm{mM} \mathrm{MgCl} 2,200 \mu \mathrm{M}$ each of dATP, dCTP, dGTP and dTTP, 40 pmoles of each primer and 2.5 units of easy Taq DNA polymerase (LGC Biotecnologia). 


\section{Determination of the IC ideal concentration}

To determine the concentration that always generated amplification of the plasmid without competing with amplification of IS6110 present in M. tuberculosis; several concentrations of this were tested. The DNA from H37Rv $M$. tuberculosis was used to test the performance of the IC in the PCR and the DNA concentrations were determined in the spectrophotometer at $A_{260}$ (GeneQuant, Bio Rad-Pharmacia). Dilutions corresponding to $100 \mathrm{pg}, 10 \mathrm{pg}, 1 \mathrm{pg}, 100 \mathrm{fg}, 10$ $\mathrm{fg}, 5 \mathrm{fg}$ and $1 \mathrm{fg}$ were added into each reaction tube that previously contained $10 \mathrm{ng}$ of total DNA of M. tuberculosis strain $\mathrm{H} 37 \mathrm{Rv}$ as reference. For the clinical specimen's amplification, the same PCR conditions were conducted. Briefly, ten from $30 \mu$ total glass matrix purified DNA were added into the PCR mix. The goal to define the ideal DNA concentration for the PCR was to verify the optimal IC concentration that did not compete with the target amplification.

\section{RESULTS}

\section{Internal control construction}

The 600-bp exogenous fragment was obtained from the pUC13 plasmid submitted to the digestion with EcoRI enzyme, excised from agarose gels and purified with commercial kits. The ends of the $600 \mathrm{bp}$ fragment to be utilized in the cloning were filled with Klenow DNA Polymerase and then linked to the pAMP-1 linearized plasmid. Exogenous DNA fragments available in the laboratory (Escherichia coli, Chlamydia, Echinococcus granulosus) were tested in the PCR to verify the unspecific annealing regions. All the tested DNAs showed unspecific sub-products in the PCR, and for this reason were considered not suitable as an IC.

In the case of the positive results for the $\mathrm{TB}$, the analyses by the agarose gel electrophoresis showed two fragments, the first corresponding to the IC (664-bp) and the second one to the IS6110 245-bp fragment. The results of the agarose gel electrophoresis were blind-read and compared to the final diagnosis.

\section{Internal control amplification}

The competition in the PCR between the IC sequence and IS6110 M. tuberculosis DNA from the clinical specimens was analyzed by the coamplification at several concentrations. Results showed that the utilization of $10 \mu \mathrm{L}$ of the DNA from the clinical specimens in PCR was the most suitable volume (data not shown). The assays with the higher volumes $(15$ or $20 \mu \mathrm{l})$ showed competition (but not inhibition) with the IC. Even if the DNA concentration was not determined, and as previously established, ten microliters was a suitable volume for the detection in PCR.

\section{Limit of detection of the IC}

The ideal IC concentration to be used with the clinical samples (sputum, blood, cerebrospinal fluid (CSF), tissues and others) was defined as $5 \mathrm{fg}$ per reaction (data not shown). This was standardized as the unique concentration for all the samples. For the standardization of the IC, the concentration was critical, too much IC DNA would compete out with the genomic DNA template, thus giving false negative results. However, when the concentration of the IC was optimally defined, the analytical sensitivity was not compromised. The inclusion of the IC should not have deleterious effects on the sensitivity of the assay. No competitive effect was detected for the $5 \mathrm{fg}$ concentration of the IC with $10 \mu \mathrm{L}$ of DNA from the clinical specimens.

\section{Amplification of M. tuberculosis from clinical specimens}

In order to determine the accuracy of the IC in detection of the inhibitors PCR was performed for 149 clinical specimens. The amplified products were visualized as two separated fragments, one of 664-bp corresponding to the IC and the other one of 245-bp of the IS fragment. Figure 1 shows the results obtained with the DNA from the clinical specimens in the laboratory. 


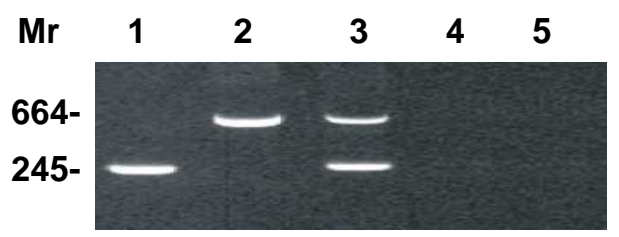

Figure 1 - Polymerase Chain Reaction results from clinical specimens analyzed by agarose gel electrophoresis. Briefly, Mr indicates the base pairs (bp) sizes, Lane 1 shows the positive diagnostic fragment of 245-bp without the IC, lane 2 shows a negative specimen only with the IC amplified (664-bp), in the lane 3 one can observe the positive result with two amplified fragments (245-bp and 664-bp). Lane 4 shows the result of an inhibited IC in a negative specimen and in lane 5 is shown the PCR mix with no DNA as a negative reaction control.

From the 149 specimens, five showed evidence of the inhibition. The inhibited negative specimens were observed, as expected, without the amplification of any fragment. These results represented a rate of the inhibition of $3.3 \%$ (see table 1). When a new aliquot of the inhibited specimen was processed, the negative and positive results consistent with the clinical data were obtained. Four samples were confirmed as the negative and one gave a positive end result.

According to the CDC, the TB diagnostic indications, when an inhibited sample was identified, a new sample or another aliquot from the same origin should be processed. This procedure has been adopted in the present work.

Table 1 - Polymerase Chain Reaction results of the analyzed specimens. All PCR results were compared to the clinical and bacteriological gold standards. The positive inhibited specimen was serum and the four negative ones correspond to 1 serum and 3 cerebrospinal fluid.

\begin{tabular}{lcc}
\hline Sample results & With inhibition & Without inhibition \\
\hline Positive & 1 & 38 \\
Negative & 4 & 111 \\
Total & 5 & 144 \\
\hline
\end{tabular}

\section{DISCUSSION}

The use of in-house PCR methods for the routine diagnostic has increased during recent years. However, impurities in the DNA preparations could inhibit the reaction and even inert components might cause inhibition (Wilson, 1997). The mechanisms of the action of the inhibitors have not yet been completely understood, but there might be chemical or physical interactions. In the diagnostic testing of highly prevalent infectious diseases, the inhibitors responsible for the false negative results represented a serious problem of the public health. The specimens that contained PCR inhibitors, characterized by the absence of the targeted diagnostic fragments in the positive samples reinforced the need to overcome the problem through an IC to effectively monitor the reaction (Wilson, 1997; Almeda et al., 2000; HonoréBouakline et al., 2003). The use of the same primer sequences to amplify the $M$. tuberculosis diagnostic fragment and the IC fragment allowed the IC to be used without increasing the laboratory work load.

All the samples were processed by an in-house PCR assay and compared to appropriate gold standards as described by Sperhacke et al. (2004). One hundred and forty four out of 149 clinical specimens had clinical and bacteriological final diagnostic concurrent with the PCR. Five specimens had discordant results, strongly suggesting the inhibition of the PCR. The retesting the inhibited samples gave four confirmed 
negative and one positive reaction. The fact that the newly processed specimens from the patients with the problematic diagnosis rendered the PCR results, which were in agreement with the final clinical diagnosis, strongly supported the utilization of an IC to help in the control of the difficult diagnostic specimens.

The proportion of the inhibited samples in this study was $3.3 \%$; slightly lower than most previous reports, in most cases ranging from 5 to $16 \%$ of inhibition (Brisson-Nöel et al., 1989; Soini et al., 1992; Ehlers et al., 1996; Almeda et al., 2000). This demonstrated that appropriate laboratory procedures helped to avoid false negative or false positive results. Apparently, the extraction methodology (glass matrix) contributed to the low level of inhibition reported.

These results were similar to Noordhoeck et al. (1994) who suggested that the use of IC was an essential feature for the reliable interpretation of the PCR with clinical specimens. The fact that a specific diagnosis could be made by the simple agarose gel electrophoresis, made its application in the developing countries practical and inexpensive. Moreover, the diagnosis can be made in a few hours, on the same day the specimens are received, and with relatively low costs. These results differed from others that reported the competition of the target DNA and control DNA in the PCR amplification procedure (Kolk et al., 1994). The utilization of an IC with the same primer-binding region as the target sequence has several advantages over the conventional multiplex PCR that uses the IC with different primer sequences. This strategy obviously eliminated the addition of another primer set, avoiding also the need of additional components or adjustment in the ionic concentration in the PCR mix. The IC should result in a longer fragment than the target as in general, the shorter fragments are more efficiently amplified. If the IC is longer reducing, the extension time used in the PCR can be used to make the reaction kinetics favor amplification of the target over the IC. It is important to emphasize that this strategy rendered an excellent IC that has been currently used in the in-house PCR tests for M. tuberculosis diagnosis. The use of an IC, composed by a cloned unrelated segment in a plasmid in the PCR mixture is promissory, because this way one can avoid the false negative results. A wide use of the IC should be done to monitor the amplification reaction, not only in Mycobacterium, but also in other pathogenic microorganisms.

\section{ACKNOWLEDGEMENTS}

To Dr. Richard Anthony of the KIT Biomedical Research Center - The Netherlands, for the valuable help in the revision of the text.

\section{RESUMO}

A PCR do elemento IS6110 para diagnóstico da Tuberculose (TB) é muito utilizada em laboratórios de pesquisa. As suas limitações incluem, a inibição da enzima Taq DNA Polimerase. A seguir descrevemos a construção de um Controle Interno (IC) e ensaios de detecção da inibição da PCR para M. tuberculosis. O IC é um fragmento de DNA de $600 \mathrm{pb}$ com os mesmos sítios de anelamento do primer, permitindo a amplificação com o fragmento diagnóstico de 245 pb. As amostras positivas fornecem um padrão de bandas referentes ao IC (664 pb) e ao fragmento diagnóstico (245 pb), e as amostras negativas apresentam apenas o fragmento correspondente ao IC. 149 amostras com diagnóstico conhecido foram analisadas por PCR introduzindo o IC em todas elas. Os resultados mostraram $3.3 \%$ de amostras sem amplificação do IC sugerindo inibição. Estas amostras quando testadas novamente mostraram resultados concordantes com os resultados clínicos. O objetivo do IC e identificar os falsos resultados negativos.

\section{REFERENCES}

Almeda, J., García, A., González, J., Quintó, L., Ventura, P. J., Vidal, R., Rufí, G., Martínez, J. A., Jiménez de Anta, M. T., Trilla, A., Alonso, P. L. (2000). Clinical evaluation of an in-house IS6110 Polymerase Chain Reaction of tuberculosis. European Journal of Clinical Microbiology and Infectious Diseases, 19, 859-867.

Balavoine, G. (1996). Identification of members of several homeobox genes in a planarian using a ligation-mediated polymerase chain reaction technique. Nucleic Acids Research, 24, 1547-1553.

Beavis, K. G., Lichty, M. B., Jungkind, D. L., Giger, O. (1995). Evaluation of Amplicor PCR for direct detection of Mycobacterium tuberculosis from 
sputum specimens. Journal of Clinical Microbiology, l 33, 2528-2536.

Brightwell, G., Pearce, M., Leslie, D. (1999). Development of internal controls for PCR detection of Bacillus anthracis. Molecular Cell Probes, 1998, 12, 367-77. Erratum in: Molecular Cell Probes, 13, 167.

Brisson-Nöel, A., Gicquel, B., Lecossier, D., LevyFrebault, V., Nassif, X., Hance, A. J. (1989). Rapid diagnosis of tuberculosis by amplification of mycobacterial DNA in clinical samples. The Lancet, 8671, 1069-1071.

Ehlers, S., Ignatius, R., Regnath, T., Hahn, H. (1996). Diagnosis of extrapulmonary tuberculosis by GenProbe amplified Mycobacterium tuberculosis direct test. Journal of Clinical Microbiology, 34, 22752279.

Eisenach, K. D., Cave, M. D., Bates, J. H., Crawford, J. T. (1990). Polymerase chain reaction amplification of a repetitive DNA sequence specific for Mycobacterium tuberculosis. The Journal of Infectious Diseases, 161, 977-81.

Eisenach, K. D., Sifford, M. D., Cave, M. D., Bates, J. H., Crawford, J. T. (1991). Detection of Mycobacterium tuberculosis in sputum samples using a polymerase chain reaction. The American Review of Respiratory Diseases, 144, 1160-1163.

Folgueira, L., Delgado, R., Palenque, E., Aguado, J. M., Noriega, A. R. (1996). Rapid Diagnosis of Mycobacterium tuberculosis bacteremia by PCR. Journal of Clinical Microbiology, 34, 512-515.

Folgueira, L., Delgado, R., Palenque, E., Noriega, A. R. (1993). Detection of Mycobacterium tuberculosis DNA in clinical samples by using a simple lysis method and polymerase chain reaction. Journal of Clinical Microbiology, 31, 1019-1021.

Honoré-Bouakline, S., Vincensini, J. P., Giacuzzo, V., Lagrange, P. H., Hermann, J. L. (2003). Rapid Diagnosis of Extrapulmonary Tuberculosis by PCR: Impact of Sample Preparation and DNA Extraction. Journal of Clinical Microbiology, 41, 2323-2329.

Jatana, S. K., Nair, M. N. G., Lahiri, K. K., Sarin, N. P. (2000). Polymerase chain reaction in the diagnosis of tuberculosis. Indian Pediatrics, 37, 375-382.

Kolk, A. H. J., Noordhoek, G. T., De Leeuw, O., Kuijper, S., Van Embden, J. D. A. (1994). Mycobacterium smegmatis strain for detection of Mycobacterium tuberculosis by PCR used as Internal control for inhibition of amplification and for quantification of bacteria. Journal of Clinical Microbiology, 32, 1354-1356.

Kudoh, S., Kudoh, T. A. (1974). A simple technique for culturing tubercle bacilli. Bulletin of the World Health Organization, 51, 71-82.
Kunakorn, M., Raksakait, K., Pracharktam, R., Sattaudom, C. (1999). Overcoming the errors of inhouse PCR used in the clinical laboratory for the diagnosis of extrapulmonary tuberculosis. The Southeast Asian Journal of Tropical Medicine and Public Health, 30, 84-90.

Li Z, Kelley C, Collins F, Rouse D, Morris S (1998). Expression of kat $\mathrm{G}$ in Mycobacterium tuberculosis is associated with its growth and persistence in mice and guinea pigs The Journal of Infectious Diseases, 177: $1030-1035$.

Noordhoek, G. T., Jolk, A. H. J., Bjune, G., Catty, D., Dale, J. W., Fine, P. E. M., Godfrey-Faussett, P., Cho, S., Shinnick, R., Svenson, S. B., Wilson, S., van Embden, J. D. A. (1994). Sensitivity and specificity of PCR for detection of Mycobacterium tuberculosis: a blind comparison study among seven laboratories. Journal of Clinical Microbiology, 32, 277-284.

Osaki, M., Adachin, H., Gomyo, Y., Yoshida, H. and Ito, H. (1997). Detection of mycobacterial DNA in formalin-fixed, paraffin-embedded tissue specimens by duplex polymerase chain reaction: Application to histopathologic diagnosis. Modern Pathology 10, 7883.

Patnaik M, Liegmann K, Peter JB (2001). Rapid Detection of smear-negative Mycobacterium tuberculosis by PCR and sequencing for Rifampin resistance with DNA extracted directly from slides. Journal of Clinical Microbiology, 39: 51-52.

Portillo-Gómez, L., Morris, S. L., Panduro, A. (2000). Rapid and efficient detection of extra-pulmonary Mycobacterium tuberculosis by PCR analysis. The International Journal of Tuberculosis and Lung Diseases, 4, 361-370.

Rossetti, M. L. R., Jardim, S. B., Rodrigues, V. F. S., Moura, A. R., Oliveira, H., Zaha, A. (1997). Improvement of Mycobacterium tuberculosis detection in clinical samples using DNA purified by glass matrix. Journal of Microbiological Methods, 28, 139-146.

Sambrook, J., Fritsch, E. F., Maniatis, T. (1989). Molecular cloning: A laboratory manual, $2^{\text {nd }}$ ed. Cold Spring Harbor Laboratory Press, Cold Spring Harbor, NY.

Singh, U. B., Seth, P. (2002). PCR diagnosis of tuberculosis: experience in India. Indian Journal of Pediatrics: 69 (Suppl 1): S-20-S-24.

Soini, H., Skurnik, M., Liipo, K., Tala, E., Viljanen, M. (1992). Detection and identification of mycobacteria by amplification of a segment of the gene coding for the 32-kDa protein. Journal of Clinical Microbiology, 30, 2025-2028. 
Sperhacke, R. D., Mello, F. C., Zaha, A., Kritski, A., Rossetti, M. L. (2004). Detection of Mycobacterium tuberculosis by a polymerase chain reaction colorimetric dot-blot assay. The International Journal of Tuberculosis and Lung Diseases, 8, 312-317.

Totsch, M., Schmid, K. W., Brommelkamp, E., Stucker, A., Puelacher, C., Sidoroff, G., Mikuz, G., Bocker, W., Dockhorn-Dworniczak, B. (1994). Rapid detection of mycobacterial DNA in clinical samples by multiplex PCR. Diagnostic Molecular Pathology, 3, 260-264.
Victor, T., du Toit, R., Van Helden, P. D. (1992). Purification of sputum samples through sucrose improves detection of Mycobacterium tuberculosis by polymerase chain reaction. Journal of Clinical Microbiology, 30, 1514-1517.

Wilson, I. G. (1997). Inhibition and facilitation of nucleic acid amplification. Applied and Environmental Microbiology, 63, 3741-3751. 